
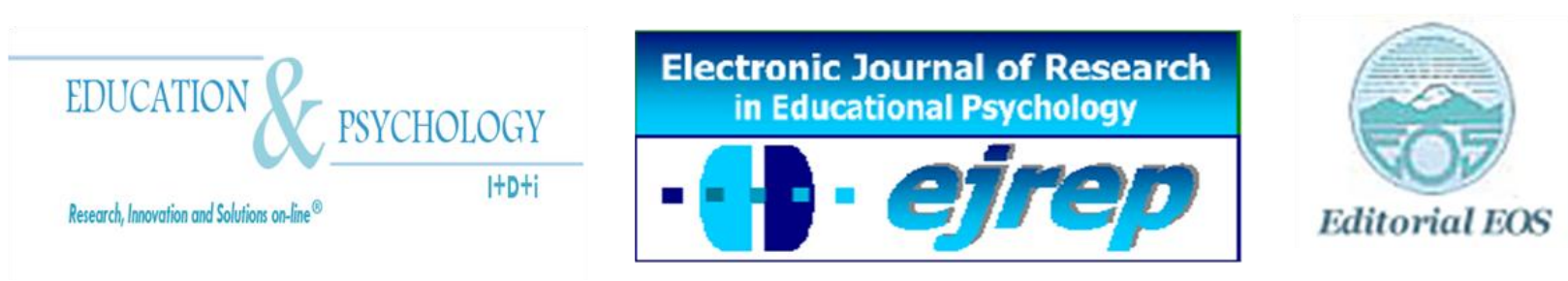

\title{
Hyperactivity in childhood as a predictor of school performance in elementary school: modifying effect of a serotonin receptor gene (5-HTR2A)
}

Laura Pulkki-Råback ${ }^{1,2}$, Helle Pullmann ${ }^{3}$, Mirka Hintsanen ${ }^{1}$, Saija Alatupa ${ }^{1}$, Niklas Ravaja ${ }^{4}$, Terho Lehtimäki ${ }^{5,6}$, Liisa Keltikangas-jarvinen ${ }^{1}$

\author{
${ }^{1}$ Department of Psychology, University of Helsinki, Finland \\ ${ }^{2}$ Finnish Institute of Occupational Health, Finland \\ ${ }^{3}$ The Estonian Centre of Behavioural and Health Sciences, \\ Department of Psychology, University of Tartu, Estonia \\ ${ }^{4}$ Center for Knowledge and Innovation Research, \\ Helsinki School of Economics, Finland \\ ${ }^{5}$ Laboratory of Atherosclerosis Genetics, Department of Clinical Chemistry, \\ Tampere University Hospital, Finland \\ ${ }^{6}$ Medical School, University of Tampere, Finland
}

\section{Finland / Estonia}

Correspondence: Laura Pulkki-Råback. Department of Psychology, Institute of Behavioral Sciences, University of Helsinki, P.O. Box 9, FIN-00014 University of Helsinki. Finland. E-mail: laura.pulkki-raback@helsinki.fi 


\begin{abstract}
Introduction. Genes have been suggested to interact with predictors of school performance, but evidence is scarce. The purpose was to examine whether a hyperactive temperament leads to different school performance, depending on variability in a serotonin receptor gene (5HTR2A).
\end{abstract}

Method. The participants were a population-based sample of 909 girls and boys in Finland aged 3-12 when their mothers rated them on the temperament dimension activity (low in activity, average in activity, or restless/hyperactive). Genomic DNA was extracted from peripheral blood samples. There were three 5-HTR2A allelic groups: T/T, T/C, and C/C. School performance was measured by grade point averages (GPA) in elementary school at the age of 12.

Results. The general linear model revealed a significant interaction between activity and the 5-HTR2A polymorphism ( $\mathrm{p}=.019)$. High activity predicted lower GPA in the T/T genotype (b $=-.25, \mathrm{p}=.003)$, and to some extent in the $\mathrm{C} / \mathrm{C}$ genotype $(\mathrm{b}=-.14, \mathrm{p}=.002)$ while no association between temperament and GPA was found in carriers of the T/C genotype $(b=.03, p=.600)$. The T/T group with high activity has poorest GPAs compared to the other allelic groups.

Conclusion: A temperament characteristic that is traditionally considered as risky may have different educational outcomes, depending on genetic vulnerability. The social or biological mechanisms whereby genes may moderate educational outcomes should be studied further.

Keywords: Activity, genes, grade point average, school performance, serotonin, temperament.

Received: 05/21/10 Initial Acceptance: 05/24/10 Definitive Acceptance: 07/08/10 


\section{Hiperactividad en la infancia como predictor de rendi- miento escolar en la educación primaria: efecto mediador del gen receptor de serotonina}

\section{Resumen}

Introducción. La carga genética se ha sugerido como un elemento que interatcúa con los predictores de la ejecución académica aunque la evidencia a este respecto es escasa. El propósito del estudio fue examinar si el temperamento hiperactivo influye en la ejecución escolar en función de la variabilidad del gen receptor de serotonina (5-HTR2A).

Método. Los participantes en el estudio fueron 909 niñas y niños de Finlandia con edades comprendidas entre los 3 y los 12 años que fueron evaluados por las madres en relación a una dimensión del temperamento (baja actividad, actividad media o inquieto/hiperactivo). El ADN fue extraído de muestras sanguíneas. Existían tres grupos alélicos del 5-HTR2A: T/T, T/C y C/C. El rendimiento académico se evaluó mediante las puntuaciones medias de curso (PMC) en educación primaria a la edad de 12 años.

Resultados. El modelo lineal general revela una interacción signitivativa entre la actividad el prolimorfirmos del 5-HTR2A ( $\mathrm{p}=.019)$. La actividad alta predecía bajo rendimiento académico en el genotipo $\mathrm{T} / \mathrm{T}(\mathrm{b}=-.25, \mathrm{p}=.003)$, y alguna relación con el genotipo $\mathrm{C} / \mathrm{C}(\mathrm{b}=-.14$, $\mathrm{p}=.002$ ), y no se encontró ninguna asociación entre el temperamento y el rendimiento académico en relación al genotipo T/C $(\mathrm{b}=.03, \mathrm{p}=.600)$. El grupo $\mathrm{T} / \mathrm{T}$ con altra actividad tenía pero rendimiento academic en comparación con el resto de grupos alélicos.

Discusión y conclusiones. Las características temperamentales han sido tradicionalmente consideradas como un factor de riesgo que puede tener diferentes efectos educativos en función de la vulnerabilidad genética. No obstante, la influencia de los mecanismos sociales y biológicos en lugar de los genes sobre los resultados educativos debe estudiarse más.

Palabras Clave: actividad, genética, puntuación escolar, ejecución escolar, serotonina, temperamento.

Recibido: 21/05/10 Aceptación Inicial: 24/05/10 Aceptación Definitiva: 08/07/10 


\section{Introduction}

Poor performance during the early school years may severely limit one's future choices of education and career (Kokko \& Pulkkinen, 2000). In order to prevent adverse life-course trajectories, identifying factors that contribute to poor performance is of importance. Temperament, which represents "biologically rooted, individual differences in behavior tendencies that are present early in life" (Bates, 1989) is known to be a central factor affecting school performance and academic achievement, even over and above the child's cognitive capacities.

High activity as a temperament characterstic is one of the most powerful temperament dimensions affecting school success in children. High activity in children is manifested as high motor tempo and vigour; highly active children usually do everything at a quicker pace than those who are low in activity (Buss, 1989). Children with such a temperament may have difficulties in sitting still in the classroom, are likely to have shorter attention span and are likely to manifest problems in concentrating at the task at hand. High activity is a strong predictor of poor school performance, learning problems, and performing below one's cognitive capacity (Carey, 1992; Fergusson, Lynskey, \& Horwood, 1997; Fischer, Barkley, Edelbrock, \& Smallish, 1990; Keogh, 2003, pp. 52-80; McGee, Prior, Williams, Smart, \& Sanson, 2002; Mullola et al., 2010). The important role played by high activity has also been shown in a study by Vitaro, Brendgen, Larose, and Tremblay (2005) who found that the hyperactivityinattention trait predicted non-completion of high school. Martin, Drew, Gaddis, and Mosley (1988) have found that children who are highly active and easily distractable (eg., who have difficulties in focusing on one task at a time) and who have low persistence (eg., give up easily when facing frustrating tasks) have difficulties in classroom learning.

Although the association between high activity and school performance is wellestablished, not all individuals who show high activity fail at school. It has been shown that some individuals continue to earn high school grades despite their highly active temperament (Johnson, McGue, \& Iacono, 2005). The protective factors that may buffer against the negative consequences of adverse temperament are poorly understood. Neurocognitive selfregulatory processes have been suggested to underlie the association between temperament and shool achievements (Checa, Rodríguez-Bailón, \& Rueda, 2008). These self-regulatory systems are at least partly under genetic control (Posner \& Rothbart, 2005), one candidate being the serotonergic system (Canli et al., 2005). Thus, individual differences in molecular 
biological systems that are determined by genetic variation may, in part, modulate the association between temperament and school outcomes. Genetic predispositions and psychological factors may work in interaction in producing academic outcomes, because some individuals may be more susceptible than others to suffer from psychological adversities (Rutter, Moffitt, \& Caspi, 2006). Such "vulnerability genes" have been identified for some disorders, such as depression or antisocial disorder (Caspi et al., 2002; Caspi et al., 2003), but evidence regarding academic performance is scarce. In the present study, it is hypothesized that a highly active temperament may be associated differently with school performance, depending on the child's genetic susceptibility.

The brain's serotonergic system, the 5-hydroxytryptamine (5-HT) plays a critical role in the regulation of mood and temperament (Reif \& Lesch, 2003). It is proposed that assay 5HT levels mainly reflect 5-HTR2A receptor function which has been associated with temperament (Moresco et al., 2002; Reif \& Lesch, 2003). It has been shown that polymorphisms in the serotonin 5-HTR2A receptor gene are associated with attention-deficit-hyperactivity disorder, which is an outcome that often is preceded by an overly active temperament (White, 1999). The 5-HT serotonin receptor has been shown to modulate outcomes associated with temperament. For instance, male carriers of the T/T genotype of the 5-HTR2A gene who were rated as hyperactive expressed high levels of hostility in adulthood whereas hyperactive carriers of the other genotypes did not express high hostility (Keltikangas-Järvinen et al., 2008). This refers to a modifying role of the 5-HTR2A gene so that high activity may have different outcomes, depending on genetic characteristics.

The purpose of the present study was to examine whether the influence of childhood temperamental activity on school achievement was moderated by the common genetic variability in the 5-HTR2A gene. We hypothesized that (a) higher childhood activity is associated with poorer school performance in adolescence (measured by grade point averages), and that (b) this association varies according to the polymorphisms of the 5-HTR2A gene. We hypothesized that carriers of the T/T polymorphism would be most adversely affected by a highly active temperament. We took into account the quality of parenting (maternal nurturance) and family socioeconomic status as confounding factors, because they are known to correlate both with child temperament and with school achievement (Díaz, 2003). 


\section{Method}

\section{Paticipants}

The participants were from the prospective, population-based Cardiovascular Risk in Young Finns study. This study includes Finnish children and adolescents representative of the whole country. Finland was divided into five areas and in each area boys and girls were randomly selected on the basis of their personal social security number from the Social Insurance Institution's population register. When the study started in 1980, a stratified random sample of 3596 healthy children and adolescents aged 3, 6, 9, 12, 15 and 18 years was taken from the population register of Finland (Åkerblom et al., 1985). In the present study, we included the four youngest cohorts who were aged 3, 6, 9, and 12 years $(n=909)$ at the baseline of the study in 1980 and who were randomly provided with genotype data. We used data from four examinations conducted at three-year intervals in 1980, 1983, 1986, and 1989.

In the present study, each participant underwent one measurement of temperament and one measurement of school achievement. At the baseline in 1980 when temperament was measured the particpants were aged $3(n=187), 6(n=225), 9(n=240)$, and $12(n=257)$. All covariates were also measured in 1980. School performance data was obtained at the age of 12 for each participant. Therefore, we used school performance data either from year 1980, 1983 , 1986, or 1989, depending on which year the participant turned 12 years of age; those who were three years of age at the baseline in 1980 were followed up until year 1989 when they had reached the age of 12 . Accordingly, participants being 6, 9, and 12 years at the baseline were followed up until they turned 12. To sum up, temperament was measured at the same time for all participants (in 1980), but school achievement was measured during different follow-up examinations depending on the age of the participant. The final sample with complete information on temperament, school achievement, and the covariates consisted of 482 girls and 427 boys (Table 1). Attrition analyses have shown that girls were overrepresented in the follow-up data, but otherwise there were no significant differences in health or socioeconomic variables between those who dropped out and those who stayed (Raitakari et al., 2008). The study plan was approved by local ethics committees, and all subjects gave their written informed consent and gave blood samples in accordance with the Helsinki Declaration. 


\section{Instruments}

Temperament. Activity was rated by participants' mothers at the baseline in 1980 by a question derived from the Health Examination Survey (Wells, 1980). Mothers were asked to choose the most accurate description for characterizing their child from the following statements: 1="My child is always controlled, stays calm even in situations were most children would become restless" (indicating low activity), 2="My child is overactive or restless only occasionally, for instance when tired" (indicating average activity), and 3="My child is continuously more active and restless than the average child" (indicating high activity). This oneitem activity scale has shown stability coefficients of .27 to .43 over different age periods in childhood and adolescence (Katainen, Räikkönen, \& Keltikangas-Järvinen, 1997) and it has been shown to predict the activity dimension of Buss and Plomin's (1984) EmotionalityActivity-Sociability temperament questionnaire (as cited in Pesonen, Räikkönen, Keskivaara, \& Keltikangas-Järvinen, 2003).

Because temperament of the 3-year-old participants may still be in considerable flux, we additionally examined changes in their temperament over two measurements (from 1980 until 1986). There was a modest but significant correlation $(r=.37, p<.0001)$ over the six-year period. There were no drastic changes in the high or low ends of hyperactivity; $100 \%$ of children who were rated as "low or average" in activity at the age of 3 were rated as "low or average" at the age of 9 . There were no children moving from the low activity category to the hyperactive category during the six-year follow-up period. Likewise, only one child who was rated as "hyperactive" at the age of three was rated as "low" in activity at the age of 9. All other children who were rated as "hyperactive" at the age of 3 were rated at least moderately high in activity at the age of 9. These findings are in line with our previous ones showing that of all possible temperament characteristics, the activity dimension of our temperament measure has highest homotypic stability over the lifecourse (Pesonen et al., 2003).

School performance. School achievement was measured at the age of 12 when the participants were in the $6^{\text {th }}$ grade of comprehensive school. Comprehensive school in Finland begins at the age of seven when students enter first grade, and is completed at the age of 15 after nine years of compulsory education. As a measure of school performance, we used Grade Point Averages (GPA) from annual school reports. GPA consisted of the mean of all school marks from different subjects (math, languages, history etc.) received during the school year. GPA is a 
rather reliable measure of school achievement, because it is done systematically every year and all students are evaluated on the same subjects. GPAs have a great significance to future education because they are widely used as entrance criteria for secondary education. In Finland, the lowest GPA is 4 (fail) and the best is 10 (excellent); thus the GPA may vary between 4 and 10. GPA varied significantly across age cohorts so that GPAs increased according to increasing age cohorts, $\left[\mathrm{F}_{(3,905)}=17.60, \mathrm{p}<.001\right]$, therefore, the values were standardized agespecifically (mean $=0$, standard deviation $=1$ ).

Childhood environment. Parental socioeconomic status (SES) was assessed at the baseline in 1980 by parents' report of their educational level (low/intermediate/high), occupational status (manual/lower nonmanual/upper nonmanual), and gross annual household income (ranging from $2523 €$ to $16819 €$ ) of the family. These three indices were standardized and summed to form an index of family socioeconomic status (Cronbach's $\alpha=.79$; average inter-item correlation $r=.56)$. The SES of the families was highly stable with a correlation coefficients of $r=.69$ ( $\mathrm{p}<.0001)$ over a 12-year follow-up period. $98 \%$ of families belonging to the lowest educational gropup at the baseline in 1980 also belonged to the lowest educational group 12 years later. Thus, there was no significant mobility within SES, and re-running the statistical analyses with later SES measurements as covariates did not change our main findings.

Maternal nurturance was rated by the participants' mothers using a scale used originally by Makkonen et al. (1981) and thereafter used in genetic-environmental studies from the Cardiovascular Risk in Young Finns data (Jokela, Keltikangas-Järvinen et al., 2007). The scale comprises of four statements ("My child is emotionally important to me"; "I enjoy spending time with my child"; "I am emotionally important to my child"; "My child allows/enables me to fulfill myself"), which were rated on a five-point scale ranging from totally disagree (1) to totally agree (5). The Cronbach's alphas of the scale were $\alpha=.66$ in the present sample (which consisted of the four youngest cohorts) and $\alpha=.77$ in the entire Cardiovascular Risk in Young Finns data consisting of six age cohorts (Pulkki, KeltikangasJärvinen, Ravaja, \& Viikari, 2003). The greater internal consistency in the entire Cardiovascular Risk in Young Finns data may be due to a more representative and slightly older sample than the one that was selected for the present study. Although the internal consistencies were only modest, previous confirmatory factor analyses have shown that these four items have significant loadings on the same latent factor reflecting the emotional nurturance provided by 
the mother to the child and correlating with the emotional atmosphere of the family (Katainen et al., 1997).

Genotyping. Genomic DNA was extracted from peripheral blood using a commercially available kit (Qiagen Inc., Hilden, Germany). DNA samples were genotyped by employing the 5' nuclease assay and fluorogenic TaqMan MGB probe (Livak, 1999) using the ABI Prism 7900HT Sequence Detection System (Applied Biosystems, Foster City, CA, USA). The nucleotide sequences of primers and allele-specific probes, labeled with the reporter dyes FAM or VIC, were deduced from sequences deposited in the GenBank database and synthesized in conjugation with Applied Biosystems using the TaqMan® Validated SNP Genotyping Assay. PCR reaction containing genomic DNA, $1 \times$ Universal PCR Master Mix, $900 \mathrm{nM}$ of each primer and $200 \mathrm{nM}$ of each probe was performed in 96-well plates using the standard protocol in a total volume of $25 \mu \mathrm{l}$. After PCR amplification, the endpoint reading of the fluorescence signal generated from each probe was measured by the allelic discrimination analysis module, resulting in clear identification of three genotypes.

\section{Statistical Analysis}

There were three possible 5-HTR2A gene allelic combinations: T/T, T/C, and C/C. An allele is one of two or more forms of the DNA sequence of a particular gene (Malats \& Calafell, 2003). Different DNA sequences (alleles) can result in different traits. Most organisms have one copy of each gene (and one allele) on each chromosome. If both alleles are the same, they are called homozygotes, and if the alleles are different, they are called heterozygotes. Thus, in our data the $\mathrm{T} / \mathrm{T}$ and $\mathrm{C} / \mathrm{C}$ were homozygous polymorphisms because the participant has inherited similar alleles from both parents, while the T/C allele is called a heterozygous polymorphism because the participant has inherited a T-alleel from one parent and a C-allele from the other. Organisms typically include multiple alleles at each genome segment (locus). Allelic variation at a locus is measurable as the number of alleles present, or the proportion of heterozygotes in the population (Malats \& Calafell, 2003).

We used the SPSS General Linear Model procedure to examine whether the association between activity and school performance differed according to various genetic polymorphisms. First we examined whether the conditions that must be present for the performance of 
moderated multiple regression analysis were met. The conditions for a moderation analysis are that a) the supposed moderator (5-HTR2A) should not be directly associated with the predictor variable (temperament), b) the moderator (5-HTR2A) should not be directly associated with the outcome variable (school grade), and c) the moderator variable (5-HTRA) should precede the predictor variable (temperament) (Kraemer, Stice, Kazdin, Offord, \& Kupfer, 2001). These conditions were met: the 5-HTR2A genotype had no main effect on school performance $(\mathrm{p}=.595)$ or with temperament $(\mathrm{p}=.86)$, and the genotypes preceded the measurement of temperament. We entered the interaction between the 5-HTR2A polymorphism (coded as a numeric variable: $1=\mathrm{T} / \mathrm{T}, 2=\mathrm{T} / \mathrm{C}, 3=\mathrm{C} / \mathrm{C})$ and activity (1=low, $2=$ medium, $3=$ high) as a predictor of school performance, controlling for age (as indicted from birth year), gender, parental SES, and maternal nurturance in the same analysis. Statistical analyses were performed using the SPSS (Version 13.0) and Statistica (Version 6.0, StatSoft) software. To examine between-group differences in GPAs, we plotted the mean values of GPAs in different allelic groups within each temperament category. Finally, we tested the association of activity with GPAs by linear regression analyses within each allelic group (T/T, T/C, C/C) to examine whether the linear association between temperament and GPA would be different in different genetic categories.

\section{Results}

Descriptive statistics for the sample are presented in Table 1. The T/T was the least frequent variant $(9.1 \%)$ of the 5 -HTR2A gene, while the $\mathrm{T} / \mathrm{C}$ and $\mathrm{C} / \mathrm{C}$ variants were almost equally common (45\% and 45.9\%). The 5-HTR2A genotype distribution did not depart significantly from the Hardy-Weinberg equilibrium $\left(\chi^{2}=1,480, p=.477\right)$. Most mothers rated their child to have an average level of temperamental activity (77\%), and children rated as highly active represented $11 \%$ of all children.

There was a significant main effect of activity on school achievement which showed that higher childhood activity was associated with poorer school performance in adolescence ( $\beta=-.09, \mathrm{p}=.007$, not shown in table).There was no significant interaction between activity and gender $(\mathrm{p}=.41)$ in predicting GPA and therefore we analyzed the genders together in subsequent analyses. There was a statistically significant interaction between the allelic variance of the 5-HTR2A and childhood activity on school performance $\left[\mathrm{F}_{(4,866)}=2.95, \mathrm{p}=.019\right]$ with 
gender, age, parental SES, and maternal nurturance as covariates. Figure 1 shows that in the $\mathrm{T} / \mathrm{T}$ and the $\mathrm{C} / \mathrm{C}$ groups, activity was negatively associated with GPAs (linear regression analyses within each allelic group showed $b s=-.31$ and.- .14 , ps=.003 and .002 ). No association between activity and GPA was found in the heterozygous T/C group , $(\mathrm{b}=.03, \mathrm{p}=.600)$.

Table 1. Descriptive statistics for the sample.

\begin{tabular}{llll}
\hline & $\mathrm{n}$ & $\%$ & Mean (SD) \\
\hline Age at the baseline: & & \multicolumn{2}{c}{$7.9(3.3)$} \\
3 years & 187 & 20.6 & \\
6 years & 225 & 24.8 & \\
9 years & 240 & 26.4 \\
12 years & 257 & 28.2
\end{tabular}

Gender:

Girls

$482 \quad 53.0$

Boys

$427 \quad 47.0$

5-HTR2A genotypes:

$\mathrm{T} / \mathrm{T}$

$83 \quad 9.1$

$\mathrm{C} / \mathrm{T}$

$409 \quad 45.0$

$\mathrm{C} / \mathrm{C}$

Temperamental activity

\begin{tabular}{llll} 
Low & 103 & 11.3 & \\
Average & 702 & 77.3 & \\
High & 104 & 11.4 & \\
GPA at age 12* & 909 & & $0.0(1.0)$ \\
\hline
\end{tabular}

* Standardized within cohorts.

Table 2 shows that highly active participants who were carriers of the T/T genotype had worse school grades (standardized GPA mean $=-.42$ ) than the other genotypes (standardized GPA means $=.31$ and -.19). This suggests that the homozygous participants (either the combination of $\mathrm{T} / \mathrm{T}$ or $\mathrm{C} / \mathrm{C}$ ) with high activity scores are likely to have poorer school success tan their heterozygous counterparts with a similar temperement. 


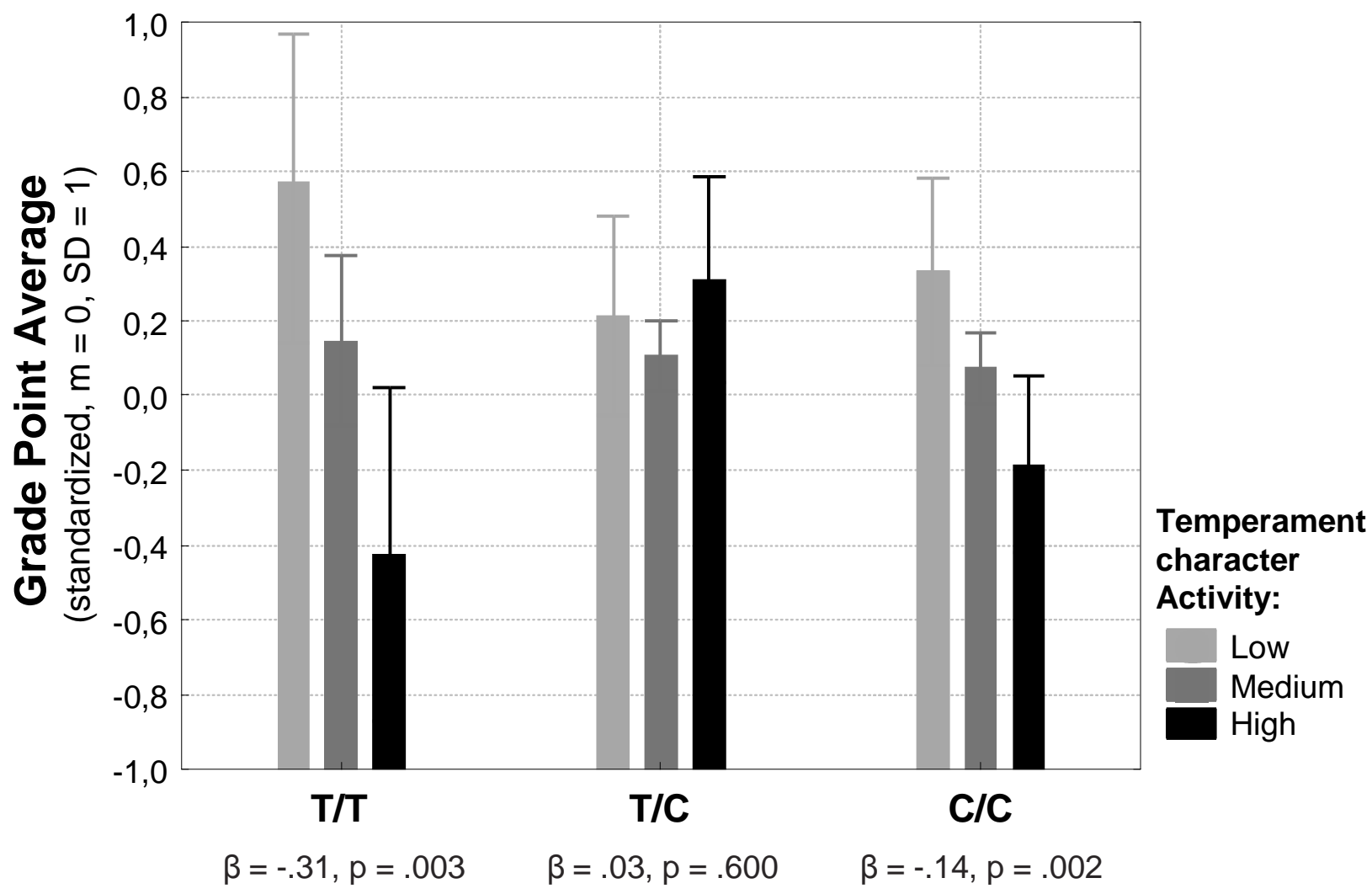

Serotonin receptor $2 \mathrm{~A}$ genotype

Figure 1. School performance in adolescence by the 5-HTR2A genotype and level of hyperactivity in childhood*.

*Interaction effect $[\mathrm{F}(4,866)=2.95, \mathrm{p}=.019]$ was computed for all covariates (age, gender, maternal nurturance and parental socioeconomic status) at their means. Vertical bars denote 0.95 confidence intervals

Table 2. Means (standard errors) of grade point average (standardized) by levels of temperamental activity and 5-HTR2A genotype, adjusted for age and gender.

\begin{tabular}{llllll}
\hline Activity & $\mathrm{T} / \mathrm{T}$ & $\mathrm{T} / \mathrm{C}$ & $\mathrm{C} / \mathrm{C}$ & F-value & $\mathrm{p}$-value \\
\hline Low & $.57(.22)$ & $.21(.14)$ & $.33(.13)$ & 1.06 & .350 \\
Medium & $.15(.12)$ & $.11(.05)$ & $.07(.05)$ & .21 & .809 \\
High & $-.42(.23)$ & $.31(.14)$ & $-.19(.12)$ & 4.61 & .012
\end{tabular}




\section{Discussion}

The present study showed that a highly active temperament predicted poorer grade point averages in adolescence which is consistent with previous literature (eg.,Carey, 1992; Fergusson et al., 1997; Fischer et al., 1990; Keogh, 2003; Martin et al., 1988; Mullola et al., 2010). A highly active temperament in our study was characterized as childhood restlessness and inability to sit still. The novel finding of this study was that the risk of highly active children to perform poorly at school in the future varies as a function of the 5-HTR2A polymorphism. To our knowledge this is the first study to show such a molecular-genetically modified association between temperament and school performance.

A highly active temperament predicted poorer school grades most strongly among carriers of the T/T genotype of the 5-HTR2A gene. Highly active children with the T/T genotype had worse grade-point averages than highly active children with the $\mathrm{T} / \mathrm{C}$ or the $\mathrm{C} / \mathrm{C}$ genotypes. Our finding is in line with previous research that has identified the T/T polymorphism to be a "susceptibility" polymorphism in the sense that carriers of it have worse outcomes than non-carriers with a similar temperament (Keltikangas-Järvinen et al., 2008).We also found that high activity predicted, although to a lesser degree, poorer school performance among carriers of the $\mathrm{C} / \mathrm{C}$ genotype. Although we did not expect such an association to be found, it lends some support from literature where subjects with the T/T or C/C phenotypes were associated with prefrontal executive functions in a similar way, while the T/C group had poorest executive function (Lane et al., 2008). Such findings on "positive or negative heterosis" (the highest or lowest phenotypic expression in heterozygotes) are known in the literature, although their functional mechanism is not entirely understood.

Our finding may reflect either a temperament-gene interaction or a gene-environment interaction. Temperament has reciprocal relations with the environment so that a child's temperament modifies the behaviour of others, such as parents or teachers. Disruptive behaviors in the classroom are very common and they constitute a major source of stress for teachers (Gotzens, Badia, Genovard, \& Dezcallar, 2010). Highly active children often misbehave in the classroom, thereby contributing to the teacher's perception of the child as "unmanageable" or "difficult" (Keogh, 2003). It is likely that such children receive more negative feedback and are faced with a challenging social environment. Therefore, our findings may reflect heightened sensitivity of $\mathrm{T} / \mathrm{T}$ carriers to respond to a stressful environment (to which they 
have contributed by their own temperament). The sensitivity of T/T carriers to environmental stress has been shown in previous studies (Jokela, Keltikangas-Järvinen et al., 2007; Jokela, Lehtimäki, \& Keltikangas-Järvinen, 2007; Keltikangas-Järvinen et al., 2008).

We used mothers' evaluations of their children's temperament which is both a strength and a limitation. Because the ratings of temperament were done by the mothers and ratings of school success were done by the teachers, we ruled out common method variance which would be a problem if the ratings were done by the same source. That being the strong point, the weak point is that the ratings may have reflected parental personality characteristics rather than the child's actual temperament. It is known that neurotic or depressed mothers view their children as more difficult to take care of (Clark, Kochanska, \& Ready, 2000; Pesonen et al., 2003). Perceiving the child as temperamentally challenging is likely to foster controlling and forceful parenting styles, even hostility toward the child (Clark et al., 2000; van den Boom \& Hoeksma, 1994). From this point of view, ratings of temperament may reflect a disturbed home atmosphere, and carriers of the T/T polymorphism are especially sensitive to the early home environment (Jokela, Keltikangas-Järvinen et al., 2007).

Finally, there may be biological mechanisms that explain the interactive association between the 5-HTR2A and temperament in predicting school success. Neuroimaging studies have shown that 5HT genotypes are associated with heightened stress-responses in the amygdala (Hariri et al., 2005) and they may control cortical regions such as the anterior cingulate (Canli et al., 2005). These brain regions also regulate temperament and emotional responses to anxiety- and fear-provoking stimuli (Hariri et al., 2005; LeDoux, 2000). If a highly active temperament and the 5-HTR2A are tied to a similar biological background, then there may be gene-gene interactions that modify the closely connected areas. Whether learning and school achievement can be explained by such mechanisms is to be examined using in vitro studies combined with molecular genetic information.

A strength of our study is that we examined a nationally representative sample of school-aged children who were followed up for a fairly long time (longest follow-up being from age 3 to age 12). There was attrition which was systematic so that females were overrepresented. Assessment of school performance was based on GPAs which may be considered a golden standard, because GPAs are assessed each year for each student according to guidelines that are nationally compatible. GPAs are also very highly related to objective measures 
of ability (Johnson et al., 2005). Moreover, daily variations in performance did not affect our results, because teachers have opportunities to observe the students' performance over a longer period than would be the case in single-time laboratory assessments of cognitive tasks.

A clear limitation is that the genetic analyses were restricted to only one serotonergic polymorphism (5-HTR2A) from a wide range of serotonin-related polymorphisms. This did not allow examination of possible complex interactions between various genes and their polymorphisms. The biological plausibility of our findings would be increased by examining the specific brain mechanisms behind the gene-temperament interaction found. At present, we do not know how the environment "gets under the skin" to alter the nervous system and generate various adverse outcomes (Caspi \& Moffitt, 2006).

Petrill and Justice (2007) have called for genetically sensitive designs to examine the important question of why some children thrive and other not in similar environments. In their words, genetic variability cannot be ignored as we search for the answer to this important question. Our findings have practical significance by showing that temperament characteristics that traditionally are considered as "risky" may lead to different outcomes depending on genetic vulnerability. This may help to understand that there are individual differences in school achievement, and some of them may be related to our genetic background. The most important message to be conveyed is that what is a risk factor for one student, might not be a risk factor for another. In an optimal case, preventive measures would be targeted at those children who are constitutionally vulnerable to suffer from adversities. Future research is needed to understand the biological mechanisms through which temperament and genes work together in producing individual differences in academic achievements. Functional imaging studies of the brain are a promising avenue of research. By scanning brain activation, it is possible to see how temperament and genes affect the activation of specific brain regions during learning. Another question is whether the effect of temperament and genes on academic achievements are generalizable to all situations or whether they are context-specific. Future research should include large samples in different educational contexts and cultures to examine the gene-by-environment variations in academic outcomes. 


\section{Acknowledgements}

This study was supported by the Academy of Finland (grant 123621 for L.P.-R., grants 209514, 209518 and 1111056 for L.K-J.), the Research Funds of the University of Helsinki (project no. 2106012 for L.P.-R.), the Social insurance institution of Finland, he Finnish Foundation of Cardiovascular Research, the Signe and Ane Gyllenberg Foundation for L.KJ,the Emil Aaltonen Foundation (T.L.) and the Tampere University Hospital Medical Fund (T.L.). The funding sources had neither been involved in the submission of the manuscript nor in the decision to publish the data. There are no conflicts of interest regarding this manuscript.

\section{References}

Bates, J. E. (1989). Concepts and measures in temperament. In G. A. Kohnstamm, J. E. Bates \& M. K. Rothbart (Eds.), Temperament in childhood (pp. 3-26). Chichester: Wiley.

Buss, A. H. (1989). Temperaments as personality traits. In G. A. Kohnstamm, J. E. Bates \& M. K. Rothbart (Eds.), Temperament in childhood (pp. 49-59). Chichester: Wiley.

Buss, A. H., \& Plomin, R. (1984). Temperament: Early developing personality traits. Hillsdale (NJ): Erlbaum.

Canli, T., Omura, K., Haas, B. W., Fallgatter, A., Constable, R. T., \& Lesch, K. P. (2005). Beyond affect: a role for genetic variation of the serotonin transporter in neural activation during a cognitive attention task. Proceeding of the National Academy of Sciences, $102,12224-12229$.

Carey, W. B. (1992). Temperament issues in the school-aged child. Pediatric Clinics of North America, 39, 569-584.

Caspi, A., McClay, J., Moffitt, T. E., Mill, J., Martin, J., Craig, I. W., et al. (2002). Role of genotype in the cycle of violence in maltreated children. Science, 297, 851-854.

Caspi, A., \& Moffitt, T. E. (2006). Gene-environment interactions in psychiatry: Joining forces with neuroscience. Nature Reviews Neuroscience, 7, 583-590. 
Caspi, A., Sugden, K., Moffitt, T. E., Taylor, A., Craig, I. W., Harrington, H., et al. (2003). Influence of life stress on depression: Moderation by a polymorphism in the 5-HTT gene. Science, 301, 386-389.

Checa, P., Rodríguez-Bailón, R., \& Rueda, M. R. (2008). Neurocognitive and temperamental systems of self-regulation and early adolsescents' social and academic outcomes. Mind, Brain and Education, 2, 177-187.

Clark, L. A., Kochanska, G., \& Ready, R. (2000). Mothers' personality and its interaction with child temperament as predictors of parenting behavior. Journal of Personality and Social Psychology, 79, 274-285.

Díaz, A. L. (2003). Personal, family, and academic factors affecting low achievement in secondary school. Electronic Journal of Research in Educational Psychology, 1, 43-66.

Fergusson, D. M., Lynskey, M. T., \& Horwood, L. J. (1997). Attentional difficulties in middle childhood and psychosocial outcomes in young adulthood. Journal of Child Psychology and Psychiatry and Allied Disciplines, 38, 633-644.

Fischer, M., Barkley, R. A., Edelbrock, C. S., \& Smallish, L. (1990). The adolescent outcome of hyperactive children diagnosed by reserach criteria: II. Academic, attentional, and neuropsychological status. Journal of Consulting and Clinical Psychology, 58, 580588.

Gotzens, C., Badia, M., Genovard, C., \& Dezcallar, T. (2010). A comparative study of the seriousness attributed to disruptive classroom behaviors. Electronic Journal of Research in Educational Psychology, 8, 33-58.

Hariri, A. R., Drabant, E. M., Munoz, K. E., Kolachana, B. S., Mattay, V. S., Egan, M. F., et al. (2005). A susceptibility gene for affective disorders and the response of the human amygdala. Archives of General Psychiatry, 62, 146-152.

Johnson, W., McGue, M., \& Iacono, W. G. (2005). Disruptive behavior and school grades: Genetic and environmental relations in 11-year olds. Journal of Educational Psychology, 97, 391-405.

Jokela, M., Keltikangas-Järvinen, L., Kivimäki, M., Puttonen, S., Elovainio, M., Rontu, R., et al. (2007). Serotonin receptor 2A gene and the influence of childhood maternal nurturance on adulthood depressive symptoms. Archives of General Psychiatry, 64, 356-360. 
Jokela, M., Lehtimäki, T., \& Keltikangas-Järvinen, L. (2007). The influence of urban/rural residency on depressive symptoms is moderated by the serotonin receptor $2 \mathrm{~A}$ gene. American Journal of Medical Genetics Part B (Neuropsychiatric Genetics), 144B, 918-922.

Katainen, S., Räikkönen, K., \& Keltikangas-Järvinen, L. (1997). Childhood temperament and mother's child-rearing attitudes: Stability and interaction in a three-year follow-up study. European Journal of Personality, 11, 249-265.

Keltikangas-Järvinen, L., Puttonen, S., Kivimäki, M., Elovainio, M., Pulkki-Råback, L., Koivu, M., et al. (2008). Serotonin receptor genes 5HT1A and 5HT2A modify the relation between childhood temperament and adulthood hostility. Genes, Brain and Behavior, 7, 46-52.

Keogh, B. K. (2003). Temperament in the classroom. Understanding individual differences (pp.52-80). Baltimore: Paul H. Brookes.

Kokko, K., \& Pulkkinen, L. (2000). Aggression in childhood and long-term employment in adulthood. A cycle of maladaptation and some protective factors. Developmental Psychology, 36, 463-472.

Kraemer, H. C., Stice, E., Kazdin, A., Offord, D., \& Kupfer, D. (2001). How do risk factors work together? Mediators, moderators, and independent, overlapping, and proxy risk factors. American Journal of Psychiatry, 158, 848-856.

Lane, H. Y., Liu, Y. C., Huang, C. L., Hsieh, C. L., Chang, Y. L., Chang, I., et al. (2008). Prefrontal executive function and $\mathrm{D}_{1}, \mathrm{D}_{3}, 5-\mathrm{HT}_{2 \mathrm{~A}}$ and $5-\mathrm{HT}_{6}$ receptor gene variations in healthy adults. Journal of Psychiatry and Neuroscience, 33, 47-53.

LeDoux, J. E. (2000). Emotion circuits in the brain. Annual Reviews in Neuroscience, 23, 155-184.

Livak, K. J. (1999). Allelic discrimination using fluorogenic probes and the 5' nuclease assay. Genetic Analysis: Biomolecular Engineering., 14, 143-149.

Makkonen, T., Ruoppila, I., Rönkä, T., Timonen, S., Valvanne, L., \& Österlund, K. (1981). Operaatio perhe - isä ja synnytys: tutkimus perhesynnytyksestä, vierihoidosta ja esikoisperheen vuorovaikutuksesta (Operation family) (No. Child Reports No A 34). Helsinki: Mannerheim League of Child Welfare. 
Malats, N., \& Calafell, F. (2003). Basic glossary on genetic epidemiology. Journal of Epidemiology \& Community Health, 57, 480-482.

Martin, R. P., Drew, K. D., Gaddis, L. R., \& Moseley, M. (1988). Prediction of elementary school achievement from preschool temperament: Three studies. School Psychology Review, 17, 125-137.

McGee, R., Prior, M., Williams, S., Smart, D., \& Sanson, A. (2002). The long-term significance of teacher-rated hyperactivity and rading ability in childhood: Findings from two longitudinal studies. Journal of Child Psychology and Psychiatry, 43, 1004-1017.

Moresco, F. M., Dieci, M., Vita, A., Messa, C., Gobbo, C., Galli, L., et al. (2002). In vivo serotonin $5 \mathrm{HT}(2 \mathrm{~A})$ receptor binding and personality traits in healthy subjects: A positron emission tomography study. Neuroimage, 17, 1470-1478.

Mullola, S., Ravaja, N., Lipsanen, J., Hirstiö-Snellmann, P., Alatupa, S., \& KeltikangasJärvinen, L. (2010). Teacher-perceived temperament and educational competence as predictors of school grade. Learning and Individual Differences, 20, 209-214.

Pesonen, A.-K., Räikkönen, K., Keskivaara, P., \& Keltikangas-Järvinen, L. (2003). Difficult temperament in childhood and adulthood: Continuity from maternal perceptions to self-ratings over 17 years. Personality and Individual Differences, 34, 19-31.

Petrill, S. A., \& Justice, L. M. (2007). Bridging the gap between genomics and education. Mind, Brain and Education, 1, 153-161.

Posner, M. I., \& Rothbart, M. K. (2005). Influencing brain networks: implications for education. Trends in Cognitive Sciences, 9, 99-103.

Pulkki, L., Keltikangas-Järvinen, L., Ravaja, N., \& Viikari, J. (2003). Child-rearing attitudes and cardiovascular risk in children: Moderating influence of parental socioeconomic status. Preventive Medicine, 36, 55-63.

Raitakari, O. T., Juonala, M., Rönnemaa, T., Keltikangas-Järvinen, L., Räsänen, L., Pietikäinen, M., et al. (2008). Cohort profile: The Cardiovascular Risk in Young Finns Study. International Journal of Epidemiology, 37, 1220-1226.

Reif, A., \& Lesch, K.-P. (2003). Toward a molecular architecture of personality. Behavioural Brain Research, 139, 1-20. 
Rutter, M., Moffitt, T. E., \& Caspi, A. (2006). Gene-environment interplay and psychopathology: Multiple varieties but real effects. Journal of Child Psychology and Psychiatry, 47, 226-261.

van den Boom, D. C., \& Hoeksma, J. B. (1994). The effect of infant irritability on motherinfant interaction: A growth-curve analysis. Developmental Psychology, 30, 581-590.

Wells, E. (1980). Behavioral patterns of children in school. Vitality Health Statistics(No. 113).

White, J. D. (1999). Personality, temperament and ADHD: A review of the literature. Personality and Individual Differences, 27, 589-598.

Vitaro, F., Brendgen, M., Larose, S., \& Tremblay, R. E. (2005). Kindergarten disruptive behaviors, protective factors, and educational achievement by early adulthood. Journal of Educational Psychology, 97, 617-629.

Åkerblom, H. K., Viikari, J., Uhari, M., Räsänen, L., Byckling, T., Louhivuori, K., et al. (1985). Atherosclerosis precursors in Finnish children and adolescents. I. General description of the cross-sectional study of 1980, and an account of the children's and families' state of health. Acta Paediatrica Scandinavica. Supplement., 318 (suppl), S49-S63 